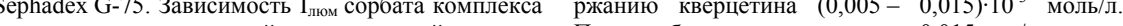
от концентрации галловой кислоты линейна в диапазоне $0,045-1,7$ мкг/мл, предел обнаружения сосавляет 0,025 мкг/мл.

Собственная люминесценция антиоксидантов в твердой фазе сорбента использована для определения хлорогеновой кислоты (ХК) в зернах кофе катехинов в чаях. Для усиления собственной люми несценции ХК использовано ее комплексообразо-

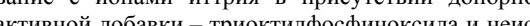
. ноге водят на фосфате алюминия Линейная область зарисимости I сорбатов комплексов от концентрции ХК наблюдается в диапазоне конщентраций 0,001 - 0,07 мкг/мл. Предел обнаружения составляет 0,035 мкг/мл.

Люминесцентный сенсор $\mathrm{Sc}(\mathrm{III})$-катехинь предложен для определения суммы катехинов. Для усиления аналитического сигнала применен лаурилулььфат натрия. Сорбцию осущесввлюг на сорбенте сефадекс G-75, $\lambda_{\text {воз6. }}=365$ нм, $\lambda_{\text {изл }}=507$ нм. редел обнаружения составляет 0,1 мкг/мл.

Собственная люминесценция лигандов, усиленная при комплексообразовании с ионами иттрия (III) или скандия (III) использована также пр определении флавоноидов - кверцетина, рутина

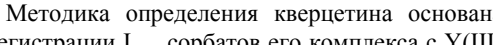
на фосфате алюминия при $\lambda$, $=360$ нм $\lambda_{\text {мал上 }}=540$ нм. $\mathrm{I}_{\text {мом }}$ сорбатов пропорциональна соде-

Предел обнаружения составляет 0,015 мкг/мл.

При определении рутина используют собственную люминесценцию его комплекса с иттрием (III) и бычьим сывороточным альбумином (БСА) на сорбенте Sephadex G-75. В этом случае осуществляется молекулярный перенос энергии, БСА выступает в качестве донора энергии возбуждения, а рутин $\left(\lambda_{\text {нзл }}=554\right.$ нм $)-$

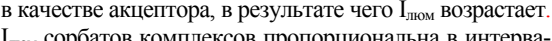

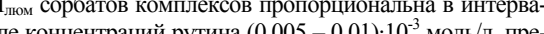
ле керцентации рулин (0,005 Определение морина основано на репирации БСА на сорбенте Sephadex G-75 при $\lambda_{\text {vin }}=521$ нм. I ${ }_{\text {mом }}$ сорбатов в этом случае пропорциональна солержанию морина в диапазоне концентраший $(0,005-$ $0,002) \cdot 10^{-3}$ моль/л, предел обнаружения 0,06 мкг/мл

Выводы

Таким образом, проведенные исследования позволяют заключить, что метод твердофазной люмитес бента, дает возможность провести предвр вите сор-

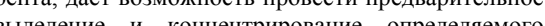
компонента и повысить чувствительность его определения. Кроме того, эти метолн позволяет определения. Кроме того, эти методы позволяют
осуществлять с помощью портативных приборов или визуально определение качества, безопасности или фальсификации пищевых продуктов.

Список литературы:

Золотов Ю.А., Иванов В.М., Амелин В.Г. Химические тест-методы анализа. - М.: УРСС. - 2006. - 304 с. Sorpion-photometric determination of phenols with polyurethane foam / S.G. Dmitrienko, E.V. Myshak, V.K. Runov,
Yu.A. Zolotov // Chem. Anal. (Warsaw). - 1995. - V.40, №1. - P. 291-298. doi:10.1016/S0003-2670(98)00394-8. Моросанова Е.И. Тонкослойная хроматография: тест-определение фенолов и папаверина / Е.И. Моросанова, А.А.
Соб̆о, Н.В. Яшин // Тезисы докл. Всероссийского симпозиума «Тест-методы химического анализа». - М. - 200 Собко, Н.В. Яшин // Тезисы докл. Всероссийского симпозиума «Тест-методы химического анализа». - М. - 2001.

4. Крушинскка О.А. Тест-оцінка антиоксидантної активності червоних вин / О.А. Крушинськая, О.А. Запорожець /
Вісник КНУ ім. Т. Шевченка, Сер. Хімія. - 2005. - т. 41. - С. 21-23.

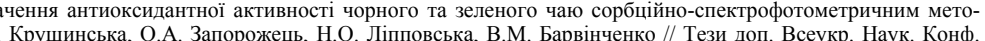
дом / О.А. Крушинська, О.А. Запорожець, Н.О. Ліпповська, В.М. Барвінченко // Тези доп. Всеукр. Наук. Конф

Тест-средства на основе пенополиуретанов для определения n-оксибензойной и галловой кислот / О.М. Медведева, С.Г. Дмитриенко, А.А. Иванов, О.А. Шпигун Sorpion-photometric determination of ascorbic acid using molybdosilicic heteropoliacid and polyurethane foam after microwave irradiation / S.G. Dmitrienko, L.V. Goncharova, A.V. Zhigulev and etc. // Anal. Chem. Acta. - 1998, М.373, №1.- P. $137-138$.

B.E. Анализ воздуха индикаторными трубками и пассивными дозиметрами // Тезисы докл. Всероссий-

Lin, L. A single sorbent for tetracycline enrichment and subsequent solid-matrix time-resolved luminescence / L. Lin, G. . Schneider, M.Y. Time-resolved luminescence screening assay for tetracyclines in chicken muscle / M.Y. Schneider, $\mathrm{G}$ Chen, M.L. Fishman // Anal. Lett, - 2004 - V.37, №10 - - P. 2067-2078. doi: 10.1081/AL-200026679.

Terbinm- sensitized luminescence optosensor for the determination of norfloxcin in biological fluids / E.Y. Lorent Mar-
tinez Y F Garcia Reyes, P Ortega Barrales, Molina Dsa A // Anal. Chem. Acta. - 2005. - V.532. - P. 159 -164. dinez, 10.1016 /j.aca. 2004.10 .066 12. Бельтюкова, С.В. Люминесцентный анализ пищевых продуктов / С.В. Бельтюкова, О.И. Теслюк, Е.О. Ливенцова
3. Бычкова А.А. Сорбционно-люминесцентное определение полифенольных соединений в пищевых продуктах, растительном сырье и фармацевтических препаратах: дис.канд. хим. наук: 02.00.02: защищена 26.03.13.

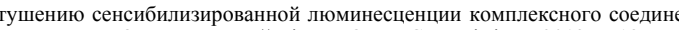
ния иона Т( (III)

\section{ДОСЛІДЖЕННЯ ТЕХНОЛОГІЧНИХ ТА ФІЗИКО-ХІМІЧНИХ ВЛАСТИВОСТЕЙ ЖИРНОЇ КОРІАНДРОВОЇ ОЛІЇ} У ПРОЦЕСІ РАФІНАЦІї

Гладкий Ф.Ф. доктор технічних наук, професор* Калина В.С. здобувач E-mail: viktoriya-kalina@mail.ru * Кафедра технології жирів та продуктів бродіння Національний технічний університет «Харківський політехнічний ін-

вул. Фрунзе, 21, м. Харків, Україна, 61002 чних наук, доцен E-mail: mariwka_11@mail.r кафедра харчових технологій
Дніпропетровський національний університет імені Олеся Гончар пр. Гагаріна, 72, м. Дніпропетровськ, Україна, 49010

Аноташія. У статті наведено результати дослідження процесу рафінації жирної коріандрової олії (жКО), яку отримують як побічний продукт переробки насіння коріандру. Визначено, що ефективним $є$ тристадійний процес ра-

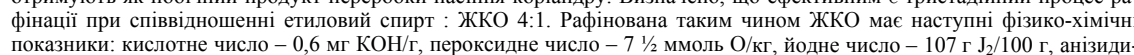
показники: кислотне число $-0,6$ мг КОН/г, пер
нове число $-2,2$; показник запомлення $-1,4631$.

Для зменшення витрат проведено ряд досліджень процесу рафінації ЖКО і встановлено можливість отриманн рафінованоі ЖКО при очищенні ії за кімнатної температури і співвідношенні етиловий спирт: ЖКО як 14:1. Дослідозволяс отримати рафіновану ЖКО 3 аналогічними показниками дкості. Використання глішерину дозволяє знизий собівартість готового продукту, але процес ускладнюеться за рахунок трудосмності розділення фаз рафінована ЖКО та розчинник. Визначен

спирт.

Аннотация. В статье рассмотрены результаты исследования процесса рафинации жирного кориандрового масла ется трехстадийный прочесс рафинации при соотношении этиловый спирт : ЖККМ 4:1. Рафинированное таким образазо ЖКМ имеет следующие физико-химические показатели: кислотное число - 0,6 мг КОН/г, перекисное число - $71 / 2$ имоль О/кг, йодное число - 107 г Ј $\mathrm{J}_{2} / 100$ г, анизидиновое число - 2,2; показатель преломления - 1,4631,

чения затрат проведен ряд исследований процесса рафинации ЖКО и установлена возможность полу-

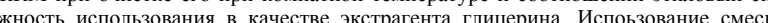
спирта и глицерина позволяет получить рафинированное ЖКМ с аналогичными показателями качества. Использование глицерина позволяет снизить себестоимость готового продукта, но процесс усложняется за счет трудоемкост разделения фаз рафинит

Ключевые слова: жирное

\section{Ветуп}

Концепція здорового харчування, а також вимоги ауки про харчувания створюють необхілість нового нологій харчових продуктів, які повинні задовольняти потреби організму людини в основних харчових речо-

Харчова наука і технологія підходу до вдосконалення складу, властивостей, тех- винах і енергії, а також сприяти профілактиці захворюруп насесобиве місце в структурі харчування всі лення планети протягом останнього часу призвонив жксних харчових продуктів. Розвиток сучасної харчовань, зберігаючи здоров'я і довголіття. Рослинні одо зменшення сировинних ресурсів для виготовтения 
вої промисловості тісно пов'язаний зі здобутками хімі- $78^{\circ} \mathrm{C}$ [11]. Доведено, що найкраще очищення ЖКО чної галузі і спрямований на використання штучних відбувасться при співвідношенні етиловий спирт до заміників харчових інгредіентів. Використання синтетичних сполук у харчових виробництвах призводить до зниження поживної цінності смакового компоненту, якості продуктів харчування i, як правило, шкодить здоров'ю людства. Піклуючись про сучасне і майбутне покоління населення нашої планети, необхідно уникати застосування в харчовій промисловості будь-яких синтетичних речовин. Для збільшення ресурсів харчо-

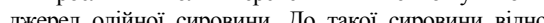
джерел олйної сировини. До такої сировини віднондрової олії (ЖКО) в якій може досягати 28\% \% [1-2]

\section{Постановка проблеми}

Наряду з багатьма актуальними проблемами харчової промисловості є розширення сировинно бази природних інгредієнтів. Серед олійної сировини перспективним $\epsilon$ насіння коріандру. Жирна

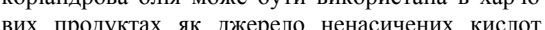
иих продуктах як джерело ненасичених кислот, набуває фізико-хімічних властивостей, які вілповідають вимогам шодо харчового продукту, лише після іiї очищення екстрагентом - рафінашії. Отже виникає потреба в дослідженні процесу рафінашій технічної коріандровоі оліі 3 метою надання їй властивостей харчового продукту.

\section{Огляд літератур}

Питання дослідження технологічних та фізикохімічних властивостей коріандрової олії розглядалос науковцями оліе-жирової галузі. Із олієвмісного насіння Coriandrum sativum зазвичай отримували ефірну олію. Вона володіє жовчогінною, відхаркувальною, болезаспокійливою і антисептичною діями, підвищус секрецію залоз травного тракту, мас здатність зменшусіння методом відгонки 3 водяною парою. При цьому отримують шрот, в якому є ЖКО, яка містить триацилглщериди петрозеліновоі кислоти [5-6]. ЖКО, як побчний продукт виробництва ефірноі коріандровоі оліб, застосовуеться у промислових виробництвах при виготовленні мастильних матеріалів [7]. У роботі [8] було науково обгрунтовано безпечне вживання ЖКО в якості нового харчового інгредієнту в раціоні людини.
Однак нерафінована ЖКО має специфічний аромат та Однак нерафінована ЖКО мас специфічний аромат т смак. Російськими вченими розроблено спосіб рафіна-

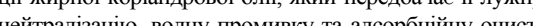

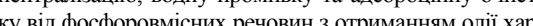
чового призначення для використання в о огїножировій промисловості [9-10]. Наведений спосіб рафінашії ЖКО $є$ багатостадійним, енерго- та ресурсовитреним. Нами у нашіональному технічному університелі «ХПІ» попередньо було досліджено процес рафінації ЖКО етиловим спиртом за його температури кипіния відбувасться при співвідношенні етиловий спирт до ЖКО як 1:4 тристадійно. При цьому кислотне число 12]. знижуеться з $17,0 \mathrm{Mг} \mathrm{КОН/г} \mathrm{до} \mathrm{0,6} \mathrm{мг} \mathrm{КОН/г} \mathrm{[1-}$ 12]. Однак залишилось нез'ясованим пит

Дослідження технологічних та фізико-хімічних властивостей ЖКО

Метою досліджень було:

вивчення процесу рафінації ЖКО гліцерином 3 метою надання ій властивостей харчового продукту;

обгрунтування параметрів та режимів процесу рафінації ЖКО екстрагентами різної природи; дослідження впливу температури та тривалості процесу рафінації на якість очищеноі ЖКО; визначення фізико-хімічних показників харчової ЖКО та іх залежностей від тривалості зберігання.

Для дослідження процесу рафінації ЖКО 3 метою надання ій властивостей харчового продукспирт та глішерин. Ці речовини дозволені світовими стандартами у виробництві харчових органічних продуктів. Крім того ці речовини виробляються із сировини, що відновлюється. Етанол дозволений, як розчинник, що використовується для виробництва харчових продуктів, а гліцерин представляє інтерес як розчинник, що має низьку вартість i може бути використаний 3 метою зниження собівартості продукціі.

Основним фізико-хімічним показником, який відрізняе рафіновану олію від нерафінованої $\epsilon$ іiі кислотне число (КЧ). КЧ промислових зразків ЖКО становить 15 - 17 мг КОН/Г [ТУУ 15.437234384-001:2010]. Рафінацію ЖКО проводили в лабораторних умовах настунним чином. змішували ЖКО з екстрагентами у необхідних пропорціях при постйу пере пролом 15 - зохвиин при ної олії. Результати дослідження представлено в таблиці 1.

3 даних таблищі можливо зробити висновок, що у процесі рафінації ЖКО етиловий спирт його суміш з гліщерином мали майже олнаковий чином, загальні витрати етилового спирту при проведенні рафінації із застосуванням тільки його у якості розчинника складають 12 частин до 1 частини ЖКО. При таких витратах розчинника КЧ рафінованої оліі досягае необхідного значення 0,6 мг КОН/г. При проведенні рафінації ЖКО сумішшю етанолу і гліцерину іх загальні витрати становлять: 7 частин етанолу і 7 частин гліцерину робки іï гліщерином та етанолом досить трудоємвплив на видалення вільних жирних кислот. Таким ний процес за рахунок ускладнення розділення багатокомпонентної суміші.

Нами попередньо було розроблено та досліджено спосіб рафінації ЖКО етанолом при температурі його кипіння $78^{\circ} \mathrm{C}[12]$ та при кімнатній

Таблиця 1 - Вплив екстр

\begin{tabular}{|c|c|c|c|c|}
\hline \multirow{2}{*}{$\begin{array}{c}\text { № стадії } \\
\text { видалення } \\
\text { вільних жи- } \\
\text { рних кислот }\end{array}$} & \multicolumn{2}{|c|}{ Рафінація ЖКО етиловим спиртом } & \multicolumn{2}{|c|}{ Рафінація ЖКО сумішшю екстрагентів } \\
\hline & \begin{tabular}{|c|} 
Співвідношення \\
ЖКО \\
до етилового спирту
\end{tabular} & $\begin{array}{c}\text { Кислотне число } \\
\text { ЖКО, } \\
\text { мг КОН/г }\end{array}$ & $\begin{array}{c}\text { Співвідношення ЖКО до суміші } \\
\text { етилового спирту та гліцерину } \\
\text { (ЖКО:етиловий спирт:гліцерин) }\end{array}$ & $\begin{array}{l}\text { Кислотне число } \\
\text { ЖКО, мг КОН/г }\end{array}$ \\
\hline 1 & $1: 4$ & 17,0 & $1: 1: 2$ & 10,07 \\
\hline 2 & $1: 4$ & 2,3 & $1: 1,5: 1,5$ & 5,18 \\
\hline 3 & $1: 4$ & 0,6 & $1: 1,5: 2,5$ & 2,42 \\
\hline 4 & - & - & 1:1:1 & 1,03 \\
\hline 5 & - & - & $1: 2: 0$ & 0,67 \\
\hline
\end{tabular}

Процес рафінації ЖКО в інертному середовискладався 3 наступних стадій:

дегазування ЖКО та етанолу у вакуумі водоструменевого насосу «Kartell

аргонування ЖКО та етанолу;

змішування ЖКО з етанолом $(96 \%)$ в необхідних пропорціях (1:4) двостадійно та $(1: 6)$ одностадійно при кімнатній температур $\sim 20^{\circ} \mathrm{C}$ протягом $5-15$ хвилин при постійному перемішуванні та декантуванні очищеної олії. у процесі рафінаціі ЖКО отримували три фракції: очищена олія, відпрацьований спирт та у вихіліій жКО перед рафінанісю), які с вінго сировиною у виробничтві миючих засобів, емульгаторів та деяких іниих темнічних речовинах [10].

Таблиця 2 - Фізико-хімі

\begin{tabular}{|c|c|c|c|c|c|c|}
\hline \multirow[b]{2}{*}{ 疍 } & \multirow[b]{2}{*}{$\begin{array}{c}\text { Назва зразка, } \\
\text { термін його зберігання }\end{array}$} & \multicolumn{5}{|c|}{ Назва показника } \\
\hline & & $\begin{array}{c}\text { Кислотне } \\
\text { число, } \\
\text { мг КОН/г }\end{array}$ & \begin{tabular}{|c|} 
Пероксидне \\
число, \\
1/2 ммоль $\mathrm{O} /$ кг
\end{tabular} & $\begin{array}{l}\text { Анізиди- } \\
\text { нове чи- } \\
\text { сло }\end{array}$ & $\begin{array}{c}\text { Йодне } \\
\text { число, } \\
\Gamma \mathrm{J}_{2} / 100 \text { г }\end{array}$ & $\begin{array}{c}\text { Показник } \\
\text { заломлення } \\
\text { при } 20^{\circ} \mathrm{C}\end{array}$ \\
\hline & Нерафінована ЖКО (щойно отримана) & 14,0 & 7 & 3,1 & 107,18 & 1,4720 \\
\hline & Нерафінована ЖКО (протягом 6 місяців) & 16,0 & 13 & 4,1 & 104,32 & 1,4726 \\
\hline 5 & Нерафінована ЖКО (протягом 12 місяців) & 17,0 & 15 & 4,6 & 102,83 & 1,4727 \\
\hline 4 & Рафінована ЖКО (щойно рафінована)* & 0,6 & 7 & 2,2 & 107,20 & 1,4631 \\
\hline & Рафінована ЖКО (протягом 6 місяців)* & 0,7 & 41 & 5,2 & 101,11 & 1,4674 \\
\hline 6 & Рафінована ЖКО (протягом 12 місяців)* & 0,8 & 306 & 14,0 & 98,45 & 1,4710 \\
\hline 7 & Рафінована ЖКО (щойно рафінована)** & 0,6 & 7 & 2,3 & 107,12 & 1,4641 \\
\hline 8 & Рафінована ЖКО (протягом 6 місяців)** & 0,7 & 41 & 5,6 & 101,05 & 1,4676 \\
\hline 9 & Рафінована ЖКО (протягом 12 місяців)** & 0,8 & 302 & 13,0 & 98,57 & 1,4712 \\
\hline & Рафінована ЖКО (щойно рафінована)*** & 0,6 & 6 & 2,1 & 107,51 & 1,4637 \\
\hline 11 & Рафінована ЖКО (протягом 6 місяців)*** & 0,7 & 38 & 6,0 & 101,30 & 1,4669 \\
\hline 12 & Рафінована ЖКО (протягом 12 місяців)*** & 0,8 & 298 & 14,1 & 98,64 & 1,4708 \\
\hline 13 & Вільні жирні кислоти (щойно рафіновані) & 87,0 & 56 & 6,3 & 100,64 & 1,4689 \\
\hline 14 & Вільні жирні кислоти (протягом 6 місяців) & 87,2 & 55 & 7,2 & 99,34 & 1,4700 \\
\hline 15 & Вільні жирні кислоти (протягом 12 місяців) & 87,2 & 57 & 7,4 & 99,56 & 1,4712 \\
\hline
\end{tabular}

** поцес рафінаціі ӝК проводили при температурі кипіння етанолу $78^{\circ} \mathrm{C}$.

**** процес рафінаії ЖКО проводили при кімнатній температурі $20^{\circ} \mathrm{C}$ (ЖКО та етиловий спирт перед рафінацією підлягали процесу аргонування).

температурі $\sim 20^{\circ} \mathrm{C}[13] .3$ метою підвищення якосрафінованої олії (мінімізація окислювальних процесів) було цікаво дослідити процес рафінаи

Якість рафінованої ЖКО оцінювалась шля-

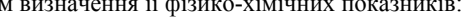
кислотне число (КЧ) згідно ДСТУ 4350:2004; пероксидне

нізидинове число згінно (АЧ) ГОСТ Р 53099

одне число згідно (ЙЧ) ДСТУ ISO 3961:2004; показник заломлення згідно ГОСТ 5482-90.

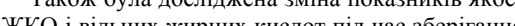
ри кімнатній температурі при дії світла.

(1) кислот представлені в таблиці 2.

харчова науга і технотогія

27 
Одержані дані експериментальних досліджень свідчать, що:

кислотне число зразків рафінованої ЖКО не залежить від температури процесу рафінаціі при всіх вищенаведених умовах та незначно залежить від тривалості іх зберігання. КЧ значному ступені характеризуе якість олії. Воно вказує на відносний вміст в ній вільних

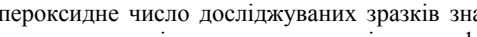
нанії та значає кількість пероксидів у ній;

анізидинове число досліджуваних зразків також залежить від доступу кисню в прочесі рафінації та тривалості їх зберігання. АЧ визначає вміст у рослинній олії другорядних продуктів окислення (альдегідів);

;их зразків залежить від тривалості іх зберігання. Воно характеризуе вміст ненасичених киллот, які входять склад олії. Велике значення йодного чис означас значний вміст ненасичених кислот, показник заломлення (n) досліджуваних зраз-
ків теж залежить від тривалості їх зберігання

Показник заломлення - важливий критерій доброякісності рослинної олії. Згірклі олії ха рактеризуються підвищеним значенням $\mathrm{n}$.

\section{Висновки}

Найкращі результати фізико-хімічних показників у досліджуваних зразках ЖКО рафінованої щойно отриманої досягаються майже при всіх вищенаведених умовах рафінації: з використанням в якості розчинника етилового спирту, етилового спирту та гліцерину, а акож за умов проведення рафінації в інертному середовищі. Ми пропонуемо проведення процесу рафінації ЖККО при сіманай температуріз метою енергозбережкня, але зі збільшеним співвідношенням Застосуралу (1.14) та з мінімальним достуном кисню. Зросування в якосі екстрагенту гліцерину дозволяе зробити процес рафінації економічним, але він $є$ трудосмним. Тому пропонуемо здійснювати рафінацію Олише етиловим спиртом.

П

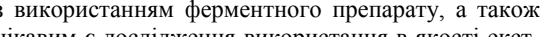
рагенту самого глішерину.

Список літератури

Kiralan, A. Ipek // Chemistry of Natural Compounds. $9240-2$

2. Romadon M.F. Oil composition of coriander (Coriandrum sativum L.) fruit-seeds / M.F. Romadon, J.T. Morsel European Food Research and Technology. - 2002. - Vol. 215. - № 3. - p. 204 - 209. DOI: 10.1007/s00217-002-0537-7

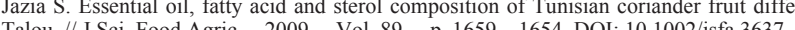
George A. Safety assessment of coriander (Coriandrum sativum L.) essential oil as a food ingredient / A. George, I.
Carabin // Food and Chemical Toxicology. - 2009. - Vol. 47. - № 1.- - p. 22- 34. DOI: 10.1016/j.fct.2008.11.006 Subbaram M. R. Determination of the Glyceride Structure of Fats. Glyceride Structure of Fats with Unusual Fatty Acid
Compositions / M. R. Subbaram, C.G. Youngs // J. Amer. Oil. Chem. Soc. - 1967. - Vol. 44. - № 7. - p. $425-428$. Compositions / M. R. Subb

6. Kleiman R. Search for New Industrial Oils: XVI. Umbelliflorae - Seed Oils Rich in Petroselinic Acid / R. Kleiman, J. Spencer // J. Amer. Oil. Chem. Soc. - 1982. - Vol. 59, № 1. - P. 29 - 38. DOI: 10.1007/BF02670064

Осейко Н.И. Исследование процесса обработки кориандрового жирного масла с целью замены им пищевых

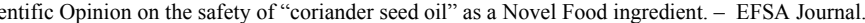
2013. - Vol. 11, №10. - article № 3422. DOI: 10.2903/j.efsa.2013.3422

Пат. РФ 글 2101336, кл. СНВЗ3/20. Сопсоб очистки жирного шева, А.Г. Анисим,

Велетовская С.Н. Опыт рафинации жирного кориандрового масла / С.Н. Велетовская, Б.Я. Стернин,

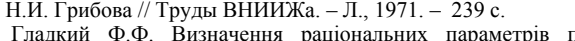
Гладкий Ф.Ф. Визначення раціональних параметрів проведення рафінацгі жирноі коріандровоі олії
Ф.Ф. Гладкий, В.С. Калина, М.В. Луценко // Харчова наука і технологія. - Одеса: ОНАХТ, 2013. - № 4 (25). - c.

12. Пат. Україна № 9213, МПК (2014.01) С11В 3/00. Спосіб рафінації жирної коріандрової олії / В.С. Калина, Ф.Ф.

DOI

\section{ОПРЕДЕЛЕНИЕ СИНТЕТИЧЕСКОГО ПИЩЕВОГО \\ КРАСИТЕЛЯ Е110 В БЕЗАЛКОГОЛЬНОМ НАПИТКЕ}

Малинка Е.В. кандидат химических наук, доцен E-mail: onahtan@mail.ru

Кафедра химии, экспертизы и безопасности пищевых продуктов Одесская национальная академия пищевых технологий ул. Канатная, 112, г.Одесса, Украина, 65039 (1) Антонович В.П. доктор химических наук, профессор

*Физико-химический институт им. А.В. Богатскогог НАН Украин Люстдорфская дорога, 86, г. Одесса, Украина, 65080

Анотація. Для кількісного визначення в безалкогольному напої синтетичного харчового барвника E110 (жовтий

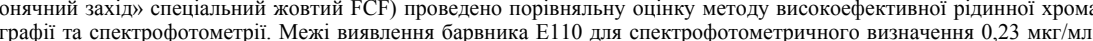
для ВЕРX-визначення 0,18 мкг/мл. Порівняння параметрів лінійності, меж виявлення, стандартних відхилень (F-тест, $\mathrm{n}=6, \mathrm{P}=0.95$ ), відносних стандартних відхилень показало узгодження результатів, отриманих за допомогою двох різ-

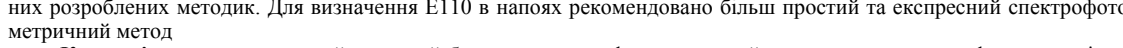
Ключові слої

Аннотация. Для определения в безалкогольном напитке синтетического пищевого красителя Е110 (желтый «солнечный для ВЭЖХ-определения 0,18 мкг/мл. Сравнение параметров линейности, пределов обнаружения, стандартных отклонений ( $\mathrm{F}$-тест, $\mathrm{n}=6, \mathrm{P}=0.95)$, относительных стандартных отклонений показало согласование результатов, полученных с помощью двух разных разработанных методик. Для рутинного и скринингового определения синтетическо

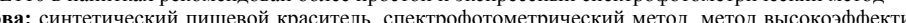
ной жидкостной хроматографии

\section{Введение}

В настоящее время в мировой практике производства продуктов питания широко применяют различные пищевые добавки, в том числе природные и синтетические красители (Е100 - Е182), которые не только выполняют технологические функции, но и улучшают органолептические характеристики продукции $[1,2]$. Широкое использование пищевых добавок позволяет недобросовестным участникам рынка производить фальсифицированные продукты питания. Известны качественная и информационная фальсификация, которые проявляются в присутствии разрешенных или запрещенных пищевых добавок, не указанных на этикетке; подмене указанной на этикетке добави друюй и превышении ее максималь-

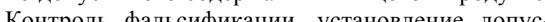
Конро врольй содержания пишевых греситей осложнен распространением на отечественном рынке импортных товаров, в которых возможно присутствие запрещенных в Украине пищевых красителей. Во многих странах запрешены такие синтетические красители E105 (Fast Yellow AB),

Харчова наука і технологія
E121 (Orcein, красный цитрусовый 2), Е123 (красный амарант, Amaranth), E126 (Ponceau 6R), лены аллергические и токсичные свойства.

Известны данные о нормах содержания синетических органических красителей в продукта питания [2]. Допустимые концентраии красителей зависят от продукта и типа красителя и составляют от 10 до $500 \mathrm{Mг} /$ кг. В то же время проводятся повторные исследования по безопасности разрешенных красителей. Так, было обнаружено что синтетические красители Е102, Е 104, Е110 Е122, Е124, Е129 вызывают гиперактивность детей [3], что явилось основанием принятия странах Европейского союза законодательной нормы об обязательном информировании об этом потребителей на етикетках с продуктами, которые содержат эти красители. Также, исходя из предложений European Food Safety Authority, допустимое суточное поступление красителя Е110 . 1 кг массы тела, в сутки, а максимальо допусти1 тxax д0 10 mг/m. 